\title{
CO Methanation for Synthetic Natural Gas Production
}

\author{
Anastasios Kambolis ${ }^{\star a b}$, Tilman J. Schildhauer ${ }^{\star b}$, and Oliver Kröcher ${ }^{\star a b}$
}

\begin{abstract}
Energy from woody biomass could supplement renewable energy production towards the replacement of fossil fuels. A multi-stage process involving gasification of wood and then catalytic transformation of the producer gas to synthetic natural gas (SNG) represents progress in this direction. SNG can be transported and distributed through the existing pipeline grid, which is advantageous from an economical point of view. Therefore, $\mathrm{CO}$ methanation is attracting a great deal of attention and much research effort is focusing on the understanding of the process steps and its further development. This short review summarizes recent efforts at Paul Scherrer Institute on the understanding of the reaction mechanism, the catalyst deactivation, and the development of catalytic materials with benign properties for $\mathrm{CO}$ methanation.
\end{abstract}

Keywords: Catalyst deactivation $\cdot \mathrm{CO}$ methanation $\cdot \mathrm{Ni} / \mathrm{Al}_{2} \mathrm{O}_{3} \cdot$ Reaction mechanism $\cdot \mathrm{SNG}$

\section{Introduction}

The energy demand has increased rapidly worldwide, especially in the emerging economies. However, petroleum sources continue to decrease, while there is an upward trend in price. Due to these issues, scientists face a unique challenge, and new opportunities arise for the development of technologies in order to meet current and future energy demands. These new technologies should minimize the environmental impact and mitigate the greenhouse phenomenon, which causes global warming and extreme weather situations. Strict emission legislation for the combustion of fuels requires the development of clean technologies, minimizing the environmental impact. ${ }^{[1-3]}$ Security concerns, resulting from the Fukushima nuclear disaster, also led to a reassessment of energy strategies worldwide. Especially after the decision to phase out nuclear energy in both Switzerland and Germany, the discussion about energy sustainability has intensified in academia, but even more so in industry. In order to satisfy the above-mentioned needs and concerns, new or less studied processes have attracted scientific interest and particularly catalysis will play an important role.

${ }^{*}$ Correspondence: Dr. A. Kambolis ${ }^{\text {ab }}$, Dr. T. J. Schildhauer ${ }^{\mathrm{b}}$, Prof. Dr. O. Kröcherab

anstitut des Sciences et Ingénierie Chimiques

Ecole Polytechnique Fédérale de Lausanne (EPFL)

$\mathrm{CH}-1015$ Lausanne

${ }^{\mathrm{b} P a u l}$ Scherrer Institute

$\mathrm{CH}-5232$ Villigen

E-mail: anastasios.kampolis@epfl.ch,

tilman.schildhauer@psi.ch, oliver.kroecher@psi.ch
Non-fossil resources make up less than $20 \%$ of global energy use, while fossil resources still dominate the energy sector and chemical industry. Several issues are associated with the use of non-renewable resources. Fossil fuel reserves are finite and the high $\mathrm{CO}_{2}$ emissions associated with their combustion is a great concern. Accordingly, renewable energy sources are needed for a future sustainable energy supply. Biomass has attracted increased interest lately because it can be converted to alternative energy using different pathways, depending on its source, type, developed conversion processes, infrastructure and economic issues. ${ }^{2,4-11]}$

A particularly interesting energy carrier is natural gas due to its low carbon to hydrogen ratio, advantageous combustion properties, the existing pipeline grid for transportation and distribution and the well-established technologies, e.g. compressed natural gas cars, heating, etc. ${ }^{[12]}$ Today, the main starting material for the manufacture of synthetic methane is coal. Coal has an enormous potential to meet energy needs, especially in the United States and China, due to its abundant resources, since reserves are expected to last for more than 150 years. Recently, environmental concerns and the abundance of biomass have motivated researchers to shift their attention towards the conversion of biomass to methane, which is also called synthetic natural gas (SNG). ${ }^{[12]}$ Both wet biomass, such as manure, crops and sewage sludge, and dry biomass, such as wood, are advantageous starting materials for SNG. This short review will focus on the methanation activities from dry biomass developed at Paul Scherrer Institute, focusing on the process chemistry, the reaction mechanism and kinetics, sulfur poisoning, the carbon- forming processes and recent attempts to develop novel catalytic materials.

\section{CO Methanation Chemistry}

The synthesis of SNG through thermochemical processes using dry biomass as feedstock follows several steps, as described in Fig. 1. ${ }^{[12,13]}$

The initial step is the gasification of biomass (or coal) using steam or oxygen to so-called producer gas. This is a mixture containing $\mathrm{H}_{2}, \mathrm{H}_{2} \mathrm{O}, \mathrm{CO}, \mathrm{CO}_{2}, \mathrm{CH}_{4}$, saturated and unsaturated hydrocarbons, tars and impurities like ash, particles, chlorine, sulphur, etc. Its composition strongly depends on the biomass source and the gasification technology. ${ }^{[12,14]}$ In the next step, gas cleaning and conditioning follows to remove the impurities which may affect the process downstream. Then, SNG is synthesized by methanation according to the reaction equations (1) and (2), also known as the Sabatier reaction. ${ }^{[15]}$ Finally, fuel upgrading follows in order to remove remaining $\mathrm{CO}_{2}, \mathrm{H}_{2}, \mathrm{H}_{2} \mathrm{O}$, etc. and achieve the final product, methane $\left(\mathrm{CH}_{4}\right)$.

$$
\begin{aligned}
& 3 \mathrm{H}_{2}+\mathrm{CO} \rightleftharpoons \mathrm{CH}_{4}+\mathrm{H}_{2} \mathrm{O} \\
& \Delta \mathrm{H}^{0}=-206 \mathrm{~kJ} / \mathrm{mol} \\
& 4 \mathrm{H}_{2}+\mathrm{CO}_{2} \rightleftharpoons \mathrm{CH}_{4}+2 \mathrm{H}_{2} \mathrm{O} \\
& \Delta \mathrm{H}^{0}=-165 \mathrm{~kJ} / \mathrm{mol}
\end{aligned}
$$

Depending on the gas mixture, the catalyst type and the reactor type, several of the above mentioned reactions occur simultaneously. If the stoichiometric ratio of $\mathrm{H}_{2} / \mathrm{CO}$ and $\mathrm{H}_{2} / \mathrm{CO}_{2}$ is 3 and 4 , respectively, reactions (1) and (2) result in the formation of the desired product. But, as seen in 


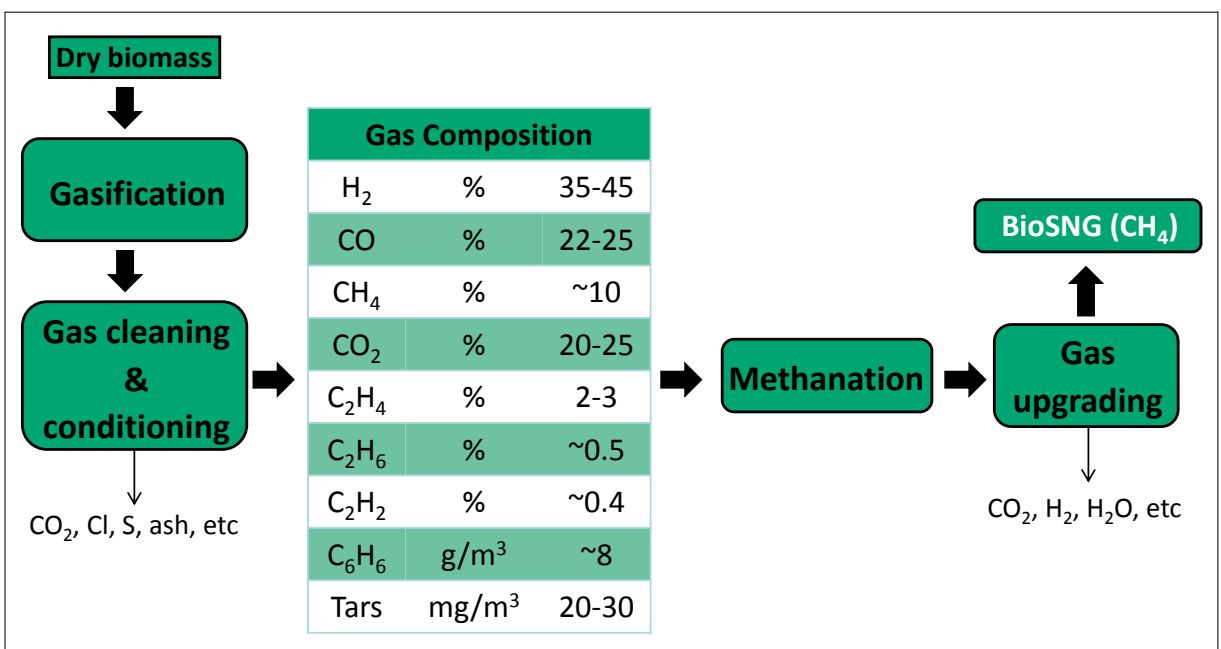

Fig. 1. General process chain from dry biomass to synthetic natural gas, applying dual fluidizedbed gasification.

Fig. 1, the $\mathrm{H}_{2} / \mathrm{CO}$ ratio after biomass gasification is not the ideal one and may vary between 0.3 and 2 . In this case, extra $\mathrm{H}_{2}$ should be fed to the reactor. $\mathrm{H}_{2} / \mathrm{CO}$ ratio can also be adjusted by the water gas shift reaction. The water gas shift reaction (3) accompanies the above-mentioned reactions, as it is initiated by the steam produced by them:

$$
\begin{aligned}
& \mathrm{H}_{2} \mathrm{O}+\mathrm{CO} \rightleftharpoons \mathrm{CO}_{2}+\mathrm{H}_{2} \\
& \Delta \mathrm{H}^{0}=-41.1 \mathrm{~kJ} / \mathrm{mol}
\end{aligned}
$$

In addition to $\mathrm{CO}$ and $\mathrm{CO}_{2}$, the producer gas from the gasification of biomass also contains methane $\left(\mathrm{CH}_{4}\right)$, ethylene $\left(\mathrm{C}_{2} \mathrm{H}_{4}\right)$, ethane $\left(\mathrm{C}_{2} \mathrm{H}_{6}\right)$, acetylene $\left(\mathrm{C}_{2} \mathrm{H}_{2}\right)$, and aromatic and poly-aromatic compounds such as benzene $\left(\mathrm{C}_{6} \mathrm{H}_{6}\right)$, naphthalene $\left(\mathrm{C}_{10} \mathrm{H}_{9}\right)$, toluene $\left(\mathrm{C}_{7} \mathrm{H}_{8}\right)$, etc. ${ }^{[14,16]}$ Due to this fact, several other reactions should be considered during the methanation step. For example $\mathrm{C}_{2} \mathrm{H}_{4}$ and $\mathrm{C}_{2} \mathrm{H}_{2}$ are hydrogenated either to $\mathrm{C}_{2} \mathrm{H}_{6}$ or $\mathrm{CH}_{4}$, according to the reactions (4)-(6): ${ }^{[17-19]}$

$$
\begin{aligned}
& \mathrm{H}_{2}+\mathrm{C}_{2} \mathrm{H}_{2} \rightarrow \mathrm{C}_{2} \mathrm{H}_{4} \\
& \Delta \mathrm{H}^{0}=-175 \mathrm{~kJ} / \mathrm{mol} \\
& \mathrm{H}_{2}+\mathrm{C}_{2} \mathrm{H}_{4} \rightarrow \mathrm{C}_{2} \mathrm{H}_{6} \\
& \Delta \mathrm{H}^{0}=-137 \mathrm{~kJ} / \mathrm{mol} \\
& (4-\times / 2) \mathrm{H}_{2}+\mathrm{C}_{2} \mathrm{H}_{x} \rightarrow 2 \mathrm{CH}_{4}
\end{aligned}
$$

Fouling is one of the most important reasons for catalyst deactivation (others: poisoning, thermal degradation, mechanical deactivation and corrosion/leaching). The most important example of fouling and one of the major problems in many catalytic processes is the deposition of carbon or coke. ${ }^{[20-22]}$ Depending on the conditions (temperature, pressure, hydrogen, type of hydrocarbon, etc.) several reactions may occur during $\mathrm{CO}$ methanation, leading to formation of carbonaceous deposits. Carbon-forming processes involve the chemisorption of different kind of carbons or condensed hydrocarbons, which then act as catalyst poisons. Carbon is usually formed by $\mathrm{CO}$ disproportionation (also known as the Boudouard reaction, (7)), unwanted polymerization and dehydrogenation of hydrocarbons (8) or dissociation of hydrocarbons (9). ${ }^{[20,22]}$

$$
\begin{aligned}
& \mathrm{CO} \rightleftharpoons \mathrm{C}+\mathrm{CO}_{2} \\
& \Delta \mathrm{H}^{0}=-172 \mathrm{~kJ} / \mathrm{mol}
\end{aligned}
$$

$$
\mathrm{C}_{\mathrm{x}} \mathrm{H}_{\mathrm{y}}+\ldots+\mathrm{C}_{\mathrm{x}} \mathrm{H}_{\mathrm{y}} \rightarrow \text { high }
$$$$
\text { molecular weight hydrocarbons }
$$$$
\rightarrow \mathrm{C}_{\alpha}, \mathrm{C}_{\beta}, \mathrm{C}_{\gamma}+\mathrm{H}_{2}
$$$$
\mathrm{C}_{\mathrm{x}} \mathrm{H}_{\mathrm{y}} \rightarrow \mathrm{C}_{\alpha}+\mathrm{H}+\mathrm{CH}_{\mathrm{x}}+
$$$$
\mathrm{C}_{2} \mathrm{H}_{\mathrm{y}}+\ldots .+\mathrm{C}_{\mathrm{n}} \mathrm{H}_{\mathrm{z}}
$$

The surface carbon may react with both $\mathrm{H}_{2}$ and $\mathrm{H}_{2} \mathrm{O}$ (gasification) again forming gaseous compounds:

$$
\begin{aligned}
& \mathrm{H}_{2}+\mathrm{C} \rightarrow \mathrm{CH}_{4} \\
& \mathrm{H}_{2} \mathrm{O}+\mathrm{C} \rightarrow \mathrm{CO}+\mathrm{H}_{2}
\end{aligned}
$$

All of the above-mentioned reactions are highly exothermic.

$\mathrm{CH}_{4}$ synthesis is a heterogeneous catalyzed process and due to its exothermic nature, it brings several challenges for the catalyst itself and the process as a whole. Thermodynamically, methanation is favored at low temperatures and high pressures. These high pressures result in a large amount of heat per reactor volume. Under these conditions, the formation of hot spots on the catalyst is inevitable. Hightemperature sites induce catalyst deactivation due to the promotion of sintering of metal sites and carbon deposition. ${ }^{[12]}$
In the following sections, studies on a commercial $\mathrm{Ni} / \mathrm{Al}_{2} \mathrm{O}_{3}$ catalyst for $\mathrm{CO}$ methanation will be presented, with a focus on the kinetics and mechanism of the process, the deactivation mechanism due to carbon deposition and sulphur poisoning, recent attempts to improve a $\mathrm{Ni} / \mathrm{Al}_{2} \mathrm{O}_{3}$ catalyst against fouling and the application of unsupported nickel nanoparticles of different morphologies.

\section{Reaction Mechanism and Kinetics for the Main Reactants during $\mathrm{CO}$ Methanation}

Over the past 50 years, a variety of papers has been published with proposed kinetics and reaction mechanisms for $\mathrm{CO}$ methanation. ${ }^{[15,23,24]}$ Applying appropriate experimental conditions, the rate of reaction could be calculated. Due to the range of different catalysts tested, experimental conditions and reactor types, several propositions have been made. Recently, a study was published applying spatially resolved measurements in a catalytic plate reactor coated with a commercial $\mathrm{Ni} / \mathrm{Al}_{2} \mathrm{O}_{3}$ catalyst aiming to investigate the influence of different reaction parameters on $\mathrm{CO}$ methanation. ${ }^{[25,26]}$ Two main models are proposed, shown in Table 1. Mechanism A proceeds on a nickel surface through the adsorption and dissociation of $\mathrm{CO}$ to adsorbed carbon. This adsorbed carbon is hydrogenated to $\mathrm{CH}_{4}$ via a four-step process. This mechanism was initially proposed by Araki and Ponec ${ }^{[27,28]}$ and was confirmed by isotopic labelling experiments and also confirmed by Galuszka et al. ${ }^{[29]}$ using infrared spectroscopy. In mechanism $\mathrm{B}$, hydrogenation of the adsorbed $\mathrm{CO}$ to $\mathrm{COH}_{\mathrm{x}}{ }^{*}$ intermediates is necessary to facilitate the splitting of carbon-oxygen bond. The remaining steps are common in both mechanisms A and B. ${ }^{225,26,30,31]}$

Recent studies on temperature programmed desorption and hydrogenation applying modulation excitation infrared spectroscopy over a commercial $\mathrm{Ni} / \mathrm{Al}_{2} \mathrm{O}_{3}$ catalyst demonstrated that the linear coordinated $\mathrm{CO}$ on $\mathrm{Ni}$ is weaker bonded and more reactive compared to the bridged CO. ${ }^{[32]}$ Isotopic labelling experiments, using ${ }^{12} \mathrm{CH}_{4},{ }^{13} \mathrm{CO}$ and $\mathrm{D}_{2}$, demonstrated the formation of ${ }^{13} \mathrm{CD}_{4},{ }^{12} \mathrm{CH}_{4},{ }^{13} \mathrm{CHD}_{3}$ and ${ }^{12} \mathrm{CD}_{4}$. Thus, ${ }^{12} \mathrm{C}$ - and ${ }^{13} \mathrm{C}$ - species seem to compete for recombination with $\mathrm{D}_{2}$ and for adsorption on $\mathrm{Ni}$ sites.

It is clear from Fig. 1 that high concentrations of $\mathrm{CO}_{2}$ are also present in the gas feed after biomass gasification. The catalytic materials designed for $\mathrm{CO}$ methanation are in general active for $\mathrm{CO}_{2}$ methanation as well.[33] However, on all these catalysts $\mathrm{CO}$ preferentially reacts with $\mathrm{H}_{2}$ due to the stronger adsorption of 
Table 1. Reaction mechanisms A and B and possible rate determining steps. Adapted from refs [25] and [26]

\begin{tabular}{|c|c|c|c|}
\hline \multirow[t]{3}{*}{ Mechanism A } & & Mechanism B & Rate determining step \\
\hline & $\mathrm{H}_{2}+2 * \leftrightarrow 2 \mathrm{H}^{*}$ & & \\
\hline & $\mathrm{CO}+* \leftrightarrow \mathrm{CO}^{*}$ & & $X$ \\
\hline \multirow[t]{18}{*}{$\mathrm{CO}^{*}+* \leftrightarrow \mathrm{C}^{*}+\mathrm{O}^{*}$} & & & $X$ \\
\hline & & $\mathrm{CO}^{*}+\alpha \mathrm{H}^{*} \leftrightarrow \mathrm{COH}_{v}^{*}+\alpha^{*}$ & $\mathrm{X}$ \\
\hline & & $\mathrm{COH}^{*}+* \leftrightarrow \mathrm{CH}^{*}+\mathrm{O}^{*}$ & $\mathrm{X}$ \\
\hline & & $\mathrm{COH}^{*}+* \leftrightarrow \mathrm{C}^{*}+\mathrm{OH}^{*}$ & $X$ \\
\hline & & $\mathrm{COH}_{v}^{*}+\alpha \mathrm{H}^{*} \leftrightarrow \mathrm{COH}_{\mathrm{w}} *+\alpha^{*}$ & $\mathrm{X}$ \\
\hline & & $\mathrm{COH}_{\mathrm{x}}^{*}+\alpha \mathrm{H}^{*} \leftrightarrow \mathrm{CH}_{\mathrm{y}} *+\mathrm{H}_{\mathrm{z}} \mathrm{O}^{*}$ & $\mathrm{X}$ \\
\hline & $\mathrm{C}^{*}+\mathrm{H}^{*} \leftrightarrow \mathrm{CH}^{*}+*$ & & $\mathrm{X}$ \\
\hline & $\mathrm{CH}^{*}+\mathrm{H}^{*} \leftrightarrow \mathrm{CH}_{2}^{*}+*$ & & $\mathrm{X}$ \\
\hline & $\mathrm{CH}_{2}^{*}+\mathrm{H}^{*} \leftrightarrow \mathrm{CH}_{3}^{*}+*$ & & $\mathrm{X}$ \\
\hline & $\mathrm{CH}_{3}^{*}+\mathrm{H}^{*} \leftrightarrow \mathrm{CH}_{4}^{*}+*$ & & \\
\hline & $\mathrm{CH}_{4}^{*} \leftrightarrow \mathrm{CH}_{4}+*$ & & \\
\hline & $\mathrm{CO}^{*}+\mathrm{O}^{*} \leftrightarrow \mathrm{CO}_{2}^{*}+*$ & & \\
\hline & $\mathrm{CO}_{2} * \leftrightarrow \mathrm{CO}_{2}+*$ & & \\
\hline & $\mathrm{O}^{*}+\mathrm{H}^{*} \leftrightarrow \mathrm{OH}^{*}+*$ & & \\
\hline & $\mathrm{OH}^{*}+\mathrm{H}^{*} \leftrightarrow \mathrm{H}_{2} \mathrm{O}^{*}+*$ & & \\
\hline & $\mathrm{H}_{2} \mathrm{O}^{*} \leftrightarrow \mathrm{H}_{2} \mathrm{O}+*$ & & \\
\hline & $\mathrm{CO}^{*}+\mathrm{OH}^{*} \leftrightarrow \mathrm{CO}_{2}^{*}+\mathrm{H}^{*}$ & & \\
\hline & $\mathrm{CO}^{*}+\mathrm{H}_{2} \mathrm{O}^{*} \leftrightarrow \mathrm{CO}_{2}^{*}+2 \mathrm{H}^{*}$ & & \\
\hline
\end{tabular}

$\mathrm{CO}$ compared to $\mathrm{CO}_{2} \cdot{ }^{[34,35]}$ Methanation of $\mathrm{CO}_{2}$ is completely suppressed until a high conversion of $\mathrm{CO}$ is achieved. It has also been reported that the rate of methanation during co-methanation of $\mathrm{CO}$ and $\mathrm{CO}_{2}$ is higher than the individual reactions, despite the preferential reaction of $\mathrm{CO}$ during co-methanation. ${ }^{[34]}$

\section{Catalyst Deactivation (Sulphur Poisoning, Carbon Deposition)}

Catalyst deactivation during $\mathrm{CO}$ methanation may be related with one of the following phenomena or a combination thereof:[12]

i) Loss of active surface, due to sintering of metal crystallites;

ii) Loss of active phase, due to its separation (physically or chemically) from the main part of the catalyst; tion;

iii) Fouling, caused by carbon deposi-

iv) Poisoning, due to inorganic compounds, where the nature of the active sites change.

Most of these processes can be limited or completely avoided at industrial scale, but understanding their impact and controlling their extent is a crucial step towards effective catalyst development and increased life-time. In the following sections, the phenomena leading to catalyst deactivation caused by sulphur and carbon species will be further described.

\subsection{Fouling by Carbon Deposition}

As referred to in the section 'Methanation Chemistry', fouling is one of the main reasons for catalyst deactivation during CO methanation, due to the conversion of $\mathrm{CO}$ and hydrocarbons that are present in the gas stream. These carbon-containing compounds tend to react with each other or the active metal (e.g. Ni), forming various types of carbon deposits or coke and leading to deactivation. Several studies have been reported on this topic as it is one of the main reasons of catalyst deactivation not only in methanation but also on reforming processes (e.g. steam or dry reforming).[20,22,36-38] The main problem of $\mathrm{CO}$ methanation from biomassderived gas is the presence of $\mathrm{C}_{2}$ species and aromatics. ${ }^{[12,14]}$ Most carbon species and coke stem from these compounds and strongly depend on the temperature, $\mathrm{H}_{2}$ and $\mathrm{CO}$ concentrations, partial pressure of $\mathrm{H}_{2} \mathrm{O}$, nickel crystallite size and the type of support. ${ }^{[23]}$ An overview of the carbon types formed during $\mathrm{CO}$ methanation is given in Table 2.

$\mathrm{CO}$ and higher hydrocarbons (e.g. $\mathrm{C}_{2}$ species, aromatics) dissociate on the surface of the catalyst to single carbon atoms, called adsorbed carbon atoms or $\mathrm{C}_{\alpha}$. These carbon atoms are the intermediate for the synthesis of $\mathrm{CH}_{4}$. When the carbon deposition rate is higher than that of the reaction with $\mathrm{H}_{2}, \mathrm{O}_{2}$ or $\mathrm{H}_{2} \mathrm{O}$ and if temperatures are below $400^{\circ} \mathrm{C}$, these carbon atoms diffuse into the bulk nickel forming bulk nickel carbide or $\mathrm{C}_{\gamma}$. With further increase of the temperature to $500{ }^{\circ} \mathrm{C}$, the adsorbed carbon atoms polymerize forming an amorphous carbon film, called $\mathrm{C}_{\beta}$. This film may cover the active metal sites, which are no longer accessible by the reactants. With time, the amorphous carbon transforms into graphitic carbon $\left(\mathrm{C}_{\mathrm{c}}\right)$, which is also referred to as encapsulating carbon $\left(\mathrm{C}_{\delta}\right)$. Graphitic carbon may also be formed in the presence of $\mathrm{C}_{2} \mathrm{H}_{2}$ and $\mathrm{C}_{2} \mathrm{H}_{4}$ in the temperature range of $500-800{ }^{\circ} \mathrm{C}$. In the same temperature region the formation of platelet carbon $\left(\mathrm{C}_{\varepsilon}\right.$ or $\mathrm{C}_{c}$ ) is also favored. Finally, a whisker type of carbon or carbon fibers may be formed in a broad temperature range from 300 up to $1000{ }^{\circ} \mathrm{C}$. This type of carbon is sometimes labelled as vermicular carbon $\left(\mathrm{C}_{\mathrm{v}}\right)$ or filamentous carbon $\mathrm{C}_{8}$. In this case, carbon diffuses into the bulk nickel (forming an intermediate nickel carbide) and lifts the nickel crystallite from the support. The catalyst is not deactivated, as the active nickel sites are still accessible to the reactants. But the continuous growth of the carbon whiskers leads to pore blockage or the loss of active phase during regeneration. Finally, pyrolytic or non-catalyst carbon $(\mathrm{G})$ is formed at temperatures above 
Table 2: Overview of the carbon types on nickel catalysts, including carbon source and formation temperature, based on refs. [13, 22, and 39]

Carbon type
Adsorbed carbon atoms $\left(\mathrm{C}_{\alpha}\right)$
Pyrolytic or non-catalyst carbon $(\mathrm{G})$
Platelet $\left(\mathrm{C}_{\varepsilon}\right.$ or $\left.\mathrm{C}_{\mathrm{c}}\right)$
Whiskers $\left(\mathrm{C}_{\mathrm{v}}\right.$ or $\left.\mathrm{C}_{\delta}\right)$
Graphitic or encapsulating $\left(\mathrm{C}_{\mathrm{c}}\right.$ or $\left.\mathrm{C}_{\delta}\right)$
Amorphous $\left(\mathrm{C}_{\beta}\right)$
Bulk carbide $\left(\mathrm{C}_{\gamma}\right)$
$600{ }^{\circ} \mathrm{C}$ in the presence of $\mathrm{C}_{2}$ hydrocarbons.
This type of carbon species is not connect-
ed with Ni crystallites, but leads to cata-
lyst deactivation by blockage of the active
metal sites.

\subsection{Sulphur Poisoning}

As discussed in more detail above, the gas mixture after biomass or coal gasification also contains hetero-atoms and inorganic compounds, such as nitrogen or sulphur species, chlorine, etc. ${ }^{[12,40]}$ Among them, sulphur-containing species are the most challenging to remove. Sulphur may be found in the form of hydrogen sulphide $\left(\mathrm{H}_{2} \mathrm{~S}\right)$, carbon disulphide $\left(\mathrm{CS}_{2}\right)$, carbonyl sulphide (COS), mercaptans and thiophenic species. ${ }^{[41]}$

In large coal-to-SNG plants, sulphur compounds are removed with the use of Rectisol ${ }^{\circledR}$ scrubbing. ${ }^{[41]}$ This method is not economically feasible in small-scale units. For these units, two gas cleaning technologies have been proposed and used, based on catalytic processes and absorber columns. In the former, sulphur-containing organic compounds are converted to $\mathrm{H}_{2} \mathrm{~S}$ and hydrocarbons, typically on a transition metal catalyst. The same catalyst favors the conversion of high hydrocarbons, also present on the gas stream, to $\mathrm{H}_{2}, \mathrm{CO}$ and low hydrocarbons through hydrogenation or steam reforming. ${ }^{[42]}$ In the second method, the absorber columns filled with an absorbing liquid, such as polyethylene glycol, effectively remove the sulphur compounds. A disadvantage of this method is that the absorber columns have to be operated at low temperatures and high pressures. The absorbers are relatively expensive and may generate liquid waste.

Independent of the method used, sulphur compounds can be found even after the sulphur removal unit. For example, after long-term measurements in the FICFB gasifier in Güssing (Austria), catalyst deactivation was observed after 190 h. ${ }^{[43]}$ Post-treatment analyses of the catalyst by XPS revealed the presence of sulphur, in-

\section{Carbon source}

$\mathrm{CO}, \mathrm{H}_{2}$

$\mathrm{CO}, \mathrm{C}_{2} \mathrm{H}_{2}, \mathrm{C}_{2} \mathrm{H}_{4}, \mathrm{C}_{2} \mathrm{H}_{6}$

$\mathrm{C}_{2} \mathrm{H}_{2}$

$\mathrm{C}_{2} \mathrm{H}_{4}$

$\mathrm{CO}$

$\mathrm{CO}, \mathrm{C}_{2} \mathrm{H}_{2}$

$\mathrm{CO}, \mathrm{C}_{2} \mathrm{H}_{4}$

Amorphous carbon $\left(\mathrm{C}_{\beta}\right)$

$\mathrm{CO}$

$\mathrm{CO}$

dicating that the removal of some species was not completely successful by $\mathrm{ZnO}$. It is well-known that only a few ppm of sulphur species are sufficient to poison a nickel catalyst. $\mathrm{H}_{2} \mathrm{~S}$ has been reported to be the main compound in the gas stream, but thiophenic species are considered more important for catalyst deactivation (Fig. 2). Sulphur is considered as a very selective poison as it is adsorbed and dissociated on nickel surfaces specifically blocking the adsorption of both $\mathrm{H}_{2}$ and $\mathrm{CO}$. Due to its strong adsorption, its removal from a nickel catalyst can only be achieved by a complex redox cycle. Using high oxygen partial pressure, nickel sulphate may be formed, which can be further removed by oxidative treatment at $\mathrm{T}>800^{\circ} \mathrm{C}$. The disadvantage of this method is the complete destruction of the catalyst, as it cannot be regenerated. ${ }^{[44]}$

\section{Catalyst Development}

The performance of the methanation reactor usually is not limited by the cata-

\section{Formation temperature}

$>600{ }^{\circ} \mathrm{C}$

$500-800^{\circ} \mathrm{C}$

$600-800{ }^{\circ} \mathrm{C}$

$300-1000^{\circ} \mathrm{C}$

$500-800^{\circ} \mathrm{C}$

$600-800^{\circ} \mathrm{C}$

$500-600^{\circ} \mathrm{C}$

$250-500^{\circ} \mathrm{C}$

$<400{ }^{\circ} \mathrm{C}$ lyst's activity, but mainly by mass transfer limitations, heat removal and the thermodynamic equilibrium. But the stability of the catalytic materials is always of great concern. Ni-based catalysts are considered to be active for CO methanation. ${ }^{[2,16,45-48]}$ Although noble metals can be even more active for this reaction, nickel is most attractive due to its lower price and abundance in nature. However, Ni-based catalysts are very sensitive to carbon formation. In the last decades, research efforts have been focused on the investigation of catalytic phenomena that occur on this material and their relation with its physicochemical properties. For this reason, several parameters, such as preparation and pretreatment conditions and catalysts composition have been extensively discussed and studied at the Paul Scherrer Institute. The aim is to introduce new catalytic systems with improved mechanical properties for fluidized-bed reactors, ${ }^{[49]}$ as well as benign properties with response to their long-term stability (sintering and coking resistance). ${ }^{[50,51]}$

Recently, a novel catalytic material was

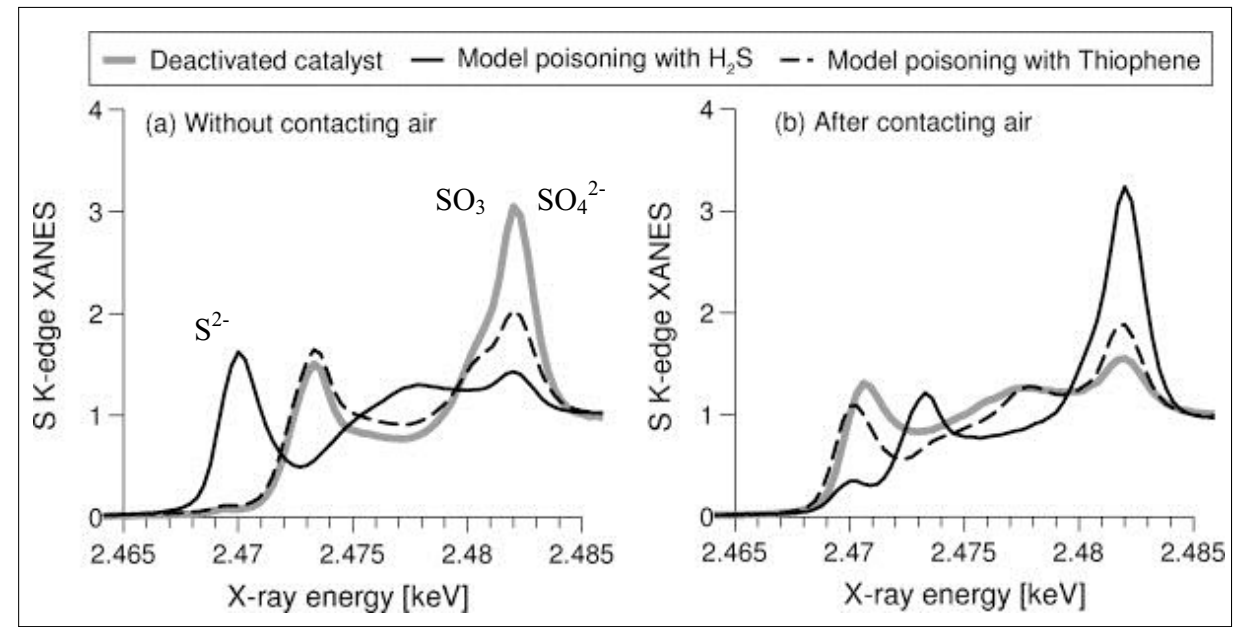

Fig. 2. (a) S K-edge XANES of the deactivated catalyst collected air-free from the methanation reactor in Güssing (Austria) and that of catalysts poisoned at $\mathrm{T}=400^{\circ} \mathrm{C}$ in model experiments with $\mathrm{H}_{2} \mathrm{~S}$ - and thiophene-doped carrier gas, respectively. (b) As with (a), but the samples was in contact with ambient air prior to analysis. Adapted from ref. [43]. 
proposed that showed remarkable stability during $\mathrm{CO}$ methanation in the presence of unsaturated hydrocarbons in the feed. A $\mathrm{Ni} / \mathrm{Al}_{2} \mathrm{O}_{3}$ catalyst was synthesized by wet impregnation composed of $15 \mathrm{wt} \%$ of $\mathrm{Ni}$, which is a much lower content compared to the commercial $\mathrm{Ni} / \mathrm{Al}_{2} \mathrm{O}_{3}$ catalyst currently applied in the methanation processes. ${ }^{[50]}$ Boron was selected as promoter for this catalytic material, because it has been reported to improve the carbon resistance of Ni-based catalysts in steam and dry reforming reactions (high temperature processes). ${ }^{[52-54]}$ Because boron and carbon atoms have similar binding energies, boron has been proposed to block step and octahedral sites of $\mathrm{Ni}$, which prevents carbon formation. As a result, carbon species remain on the surface, where they can be easily removed. ${ }^{[55]}$ In this work, boron was introduced as a promoter aiming at improved stability and carbon resistance of $\mathrm{Ni} / \mathrm{Al}_{2} \mathrm{O}_{3}$ for the low temperature $\mathrm{CO}$ methanation in the presence of unsaturated hydrocarbons $\left(\mathrm{C}_{2} \mathrm{H}_{4}\right)$ in the reaction feed. The catalysts were synthesized by wet impregnating nickel and boron precursors simultaneously or sequentially on a commercial $\gamma-\mathrm{Al}_{2} \mathrm{O}_{3}$ support. The stability tests were conducted at $593 \mathrm{~K}$ and $\mathrm{GHSV}=120000 \mathrm{mLg}^{-1} \mathrm{~h}^{-1}$ under $25 \mathrm{vol} \% \mathrm{H}_{2}, 5$ vol.\% CO, $2000 \mathrm{ppm}$ $\mathrm{C}_{2} \mathrm{H}_{4}$ (bal. $\mathrm{N}_{2}$ ). When $\mathrm{C}_{2} \mathrm{H}_{4}$ was not present in the reaction feed, $\mathrm{Ni} / \mathrm{Al}_{2} \mathrm{O}_{3}$ remained stable during the $4 \mathrm{~h}$ catalytic test. In contrast, in the presence of $\mathrm{C}_{2} \mathrm{H}_{4}, \mathrm{Ni} / \mathrm{Al}_{2} \mathrm{O}_{3}$ lost $\sim 20 \%$ of its initial activity within $4 \mathrm{~h}$. Co-addition of nickel and boron on $\mathrm{Al}_{2} \mathrm{O}_{3}$ resulted in a catalytic material stable with time on stream, as no deactivation was observed. The temperature programmed oxidation (TPO) results recorded after the stability tests exhibited significantly different $\mathrm{CO}_{2}$ desorption peaks at the lower temperature region $(450-700 \mathrm{~K})$. The thermogram of the $\mathrm{Ni} / \mathrm{Al}_{2} \mathrm{O}_{3}$ catalyst after exposure to ethylene was dominated by a strong $\mathrm{CO}_{2}$ desorption peak centered at $560 \mathrm{~K}$, which was attributed to nickel carbide and amorphous carbon species. This peak vanished in the presence of boron. ${ }^{[50]}$

In order to elucidate this observation, the catalytic materials were characterized using transmission electron microscopy (HR-TEM, HAADF-STEM), X-ray diffraction (XRD), ${ }^{11} \mathrm{~B}-\mathrm{MAS}$ NMR, and Raman spectroscopy. The XRD results indicate that the $\mathrm{NiO}$ crystallite size was larger on the boron-containing catalyst. This result is also consistent with the HAADFSTEM results. Although literature predicts that boron may control the metal particle size, this effect was not observed. Boron seems to act as flux, similar to single crystal growth, increasing ion mobility and releasing strain. But in this case, the low amount of boron ions led to an increase of the average $\mathrm{NiO}$ particle size. The effect of boron on the morphology of the materials was also evident in the HAADF-STEM images from the several dark areas on the $\mathrm{NiO}$ particles. These dark areas suggest that either these regions contain material with lower mass than $\mathrm{Ni}$ or the thickness is locally decreased. It was proposed that these dark regions correspond to non-interconnected pores of $c a .3 \mathrm{~nm}$ diameter formed on nickel particles in the presence of boron. EELS measurements on the B K-edge confirmed that these dark areas contain boron species. The close interaction of nickel and boron was confirmed by ${ }^{11}$ B-MAS NMR and Raman spectroscopy. NMR indicated that boron atoms interact with the paramagnetic nickel species and only part of the magnetization is detected. Increased vibration in the Raman spectra at $800-900 \mathrm{~cm}^{-1}$, assigned to symmetric and anti-symmetric vibrational modes of $\mathrm{M}-\mathrm{O}-\mathrm{M}$ bridges $(\mathrm{M}=\mathrm{Ni}$ and/or $\mathrm{B})$ also
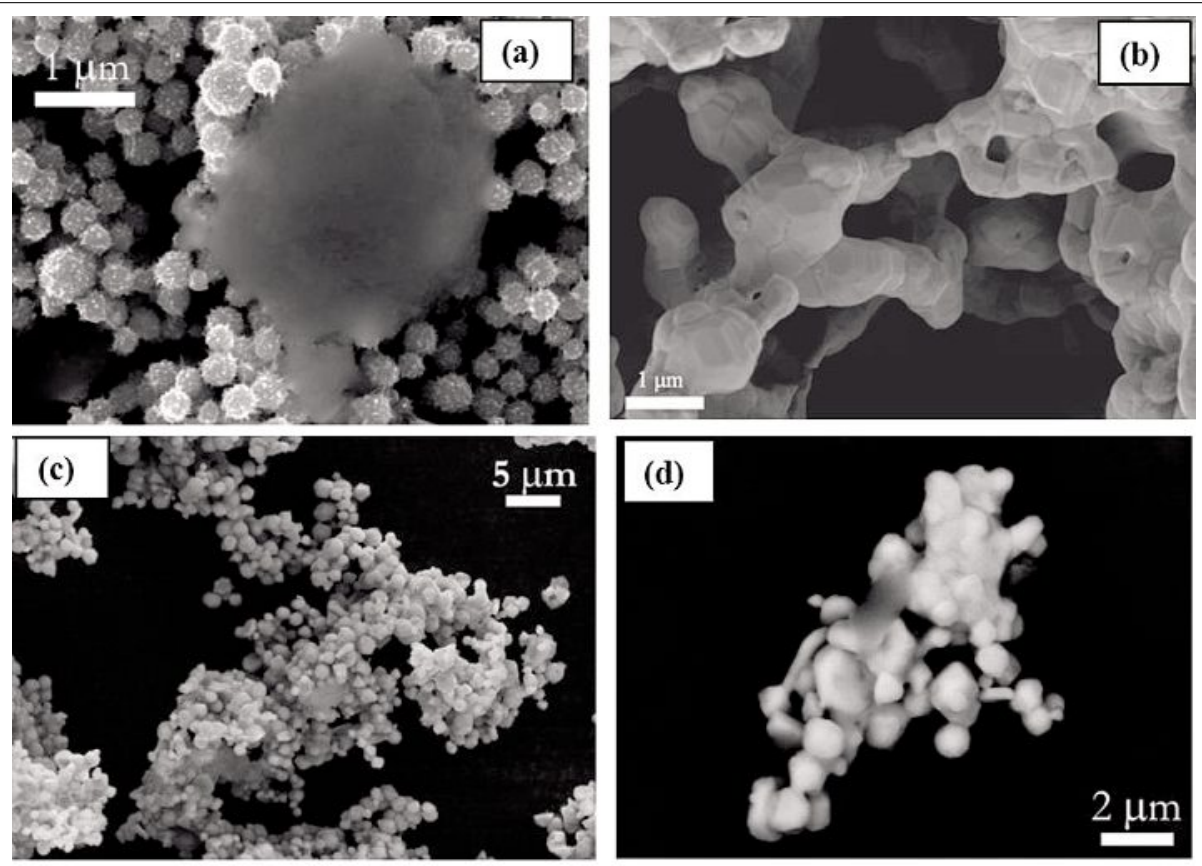

(e)

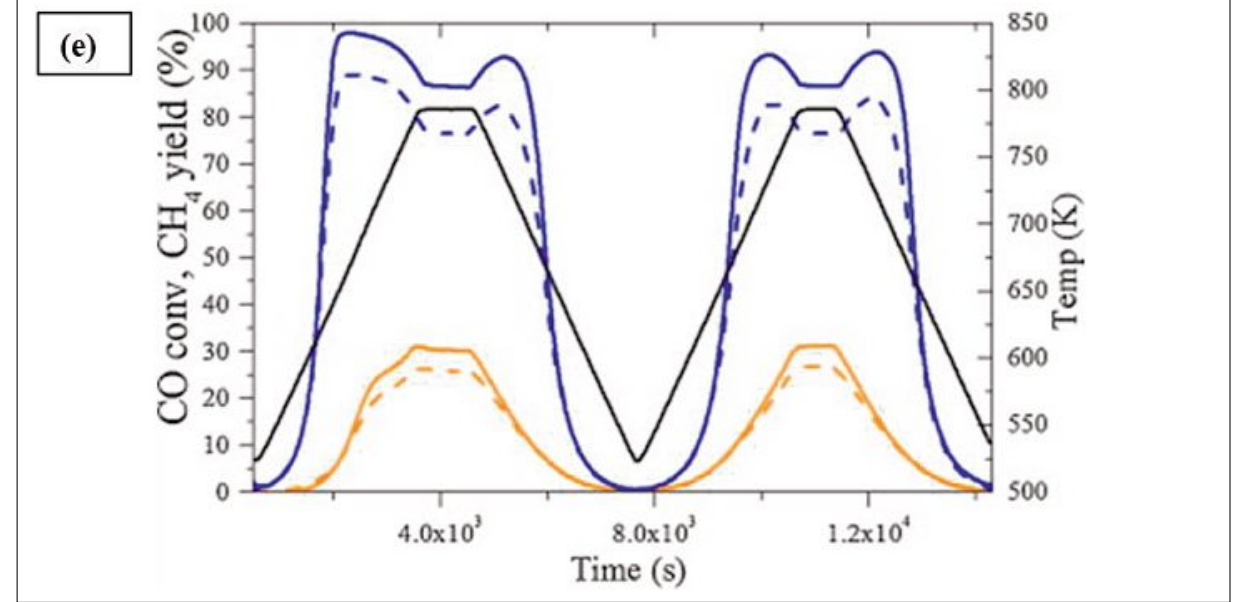

Fig. 3. SEM images of the catalyst before (a: spiky NPs, c: commercial particles) and after (b: spiky NPs, d: commercial particles) the catalytic tests. (e) Test of catalytic $\mathrm{CO}$ methanation with spiky NPs (blue line) and commercial particles (yellow line). The black line corresponds to the temperature in the catalyst bed. Adapted from ref. [51].

confirms the above statements. In summary, it can be stated that a novel catalytic material was developed with enhanced stability against carbon deposition for the low temperature $\mathrm{CO}$ methanation reaction. This material is a potential candidate tors. [50]

Another approach for new types of $\mathrm{CO}$ methanation catalysts involved the development of modern engineered materials. Nickel nanoparticles were synthesized by means of a Segmented Flow Tubular reactor (SFTR), using the polyol method. Several synthesis parameters, like precursor, tem, reaction time, were investigated to tune the particle surface morphology and size and study their influence on the catalytic properties. ${ }^{[51]}$ With the use of hydrazine $\left(\mathrm{N}_{2} \mathrm{H}_{4}\right)$ the surface morphology was successfully controlled, which varied from raspberry-like to spiky nanoparticles 
of $c a .160 \mathrm{~nm}$ size (Fig. 3a-d). In all cases a substructure of smaller primary particles of 8-16 nm size was detected.

The catalytic performance of all $\mathrm{Ni}$ NPs was evaluated for $\mathrm{CO}$ methanation in a fixed-bed reactor performing several heating ramps from 250 to $500{ }^{\circ} \mathrm{C}$ (Fig. $3 \mathrm{e})$. The thermal treatment under operando conditions allowed the formation of catalyst, in a sponge-like morphology. This morphology can be developed only from nanoparticles and not from nickel particles in the micrometer range (reference commercial material). This sponge structure proved to be relatively active, stable and reproducible, but is still far from displaying the catalytic properties of the commercial $\mathrm{Ni} / \mathrm{Al}_{2} \mathrm{O}_{3}$ catalyst. However, it is a first step towards the development of advanced engineered materials with tailored properties.

\section{Conclusions and Outlook}

Production of synthetic natural gas from biomass is considered to be an important process for a future sustainable energy system. In recent years, many research groups have focused on the further development of all process steps, from gasification of biomass to the SNG synthesis. In-depth study of the reaction mechanism and the deactivation pathways due to carbonaceous deposits and sulphur poisoning proved to be crucial for a further development of the catalysts with the aim to improve the process efficiency. Recent catalyst development strategies led to materials with benign properties for both fixed-bed and fluidized-bed reactors. These materials, based on nickel, show unique properties with respect to their long-term stability against sintering and coking.

The presence of unsaturated hydrocarbons is a challenge for the long-term catalyst stability and their conversion to less reactive species is of great importance. The understanding of their influence on the fundamental level is still lacking and further research efforts are needed for clarifying their impact on catalyst deactivation, which will allow the whole process to be further optimized. Additionally, since $\mathrm{CO}$ methanation technology is moving towards fluidized-bed reactors, the development of mechanically stable catalytic materials with improved attrition properties is a research direction of increasing significance.

\section{Acknowledgements}

The Swiss Competence Center Energy and Mobility (CCEM) under the project ARRMATplus is acknowledged for financial support.
[1] D. Rennard, R. French, S. Czernik, T. Josephson, L. Schmidt, Int. J. Hydrogen Energy 2010, 35, 4048 .

[2] 'Catalysis for Alternative Energy Generation', Eds. L. Guczi, A. Erdohelyi, Springer, New York, 2012.

[3] D. M. Drab, H. D. Willauer, M. T. Olsen, R. Ananth, G. W. Mushrush, W. Baldwin, D. R. Hardy, F. W. Williams, Energy \& Fuels 2013 , 27, 6348.

[4] D. Mohan, C. U. Pittman,, P. H. Steele, Energy \& Fuels 2006, 20, 848

[5] A. G. Gayubo, T. Aguayo, A. Atutxa, R. Aguado, Ind. Eng. Chem. Res. 2004, 43, 2610.

[6] A. G. Gayubo, A. T. Aguayo, A. Atutxa, R. Aguado, M. Olazar, J. Bilbao, Ind. Eng. Chem. Res. 2004, 43, 2619.

[7] W. D. Michalak, G. a. Somorjai, Top. Catal. 2013, 56, 1611.

[8] S. S. Akarmazyan, P. Panagiotopoulou, A. Kambolis, C. Papadopoulou, D. I. Kondarides, Appl. Catal. B Environ. 2012, 2, 1.

[9] P. D. Vaidya, A. E. Rodrigues, Chem. Eng. Technol. 2009, 32, 1463

[10] P. Panagiotopoulou, D. I. Kondarides, X. E. Verykios, Ind. Eng. Chem. Res. 2011, 50, 523.

[11] P. Panagiotopoulou, C. Papadopoulou, H. Matralis, X. Verykios, Wiley Interdiscip. Rev. Energy Environ. 2014, 3, 231.

[12] J. Kopyscinski, T. J. Schildhauer, S. M. A. Biollaz, Fuel 2010, 89, 1763.

[13] T. J. Schildhauer, in 'Synthetic Natural Gas from Coal, Dry Biomass Power-to-Gas Applications', Eds. T. J. Schildhauer, S. M. A. Biollaz, Wiley And Sons, New York, 2016.

[14] A. Dufour, E. Masson, P. Girods, Y. Rogaume, A. Zoulalian, Energy \& Fuels 2011, 25, 4182.

[15] P. Sabatier, J. B. Senderens, Acad. Sci. 1902, 314, 514.

[16] I. Czekaj, F. Loviat, F. Raimondi, S. M. A. Biollaz, A. Wokaun, Appl. Catal. A Gen. 2007, 329,68 .

[17] E. Kok, N. Cant, D. Trimm, J. Scott, Catal. Today 2011, 178, 79

[18] D. L. Trimm, I. O. Y. Liu, N. W. Cant, Appl. Catal. A. Gen. 2010, 374, 58

[19] D. L. Trimm, N. W. Cant, I. O. Y. Liu, Catal. Today 2011, 178, 181.

[20] C. H. Bartholomew, Appl. Catal. A Gen. 2001, $212,17$.

[21] C. H. Bartholomew, H. Hsieh, Appl. Catal. 1988, 36,147

[22] C. H. Bartholomew, Catal. Rev. 1982, 24, 67.

[23] J. R. H. Ross, 'Metal Catalysed Methanation and Steam Reforming', Royal Society of Chemistry, 1982

[24] S. Eckle, Y. Denkwitz, R. J. Behm, J. Catal. 2010, 269, 255

[25] J. Kopyscinski, T. J. Schildhauer, F. Vogel, S. M. A. Biollaz, A. Wokaun, J. Catal. 2010, 271, 262.

[26] J. Kopyscinski, 'Production of Synthetic Natural Gas in a Fluidized Bed Reactor - Understanding the Thermodynamic, Mass Transfer and Kinetic Effects', Dissertation, ETH Zürich, 2009.

[27] M. Araki, V. Ponec, J. Catal. 1976, 44, 439

[28] V. Ponec, Catal. Rev. - Sci. Eng. 1978, 18, 151.

[29] J. Galuszka, J. Chang, Y. Amenomiya, J. Catal. 1981, $68,172$.
[30] M. P. Andersson, F. Abild-Pedersen, I. N. Remediakis, T. Bligaard, G. Jones, J. Engbæk, O. Lytken, S. Horch, J. H. Nielsen, J. Sehested, J. Catal. 2008, 255, 6.

[31] J. W. E. Coenen, P. F. M. T. van Nisselrooy, M. H. J. M. de Croon, P. F. H. A. van Dooren, R. Z. C. van Meerten, Appl. Catal. 1986, 25, 1.

[32] J. Zarfl, D. Ferri, T. J. Schildhauer, J. Wambach, A. Wokaun, Appl. Catal. A Gen. 2015, 495, 104.

[33] G. A. Mills, F. W. Steffgen, Catal. Rev. 1973, 8, 159.

[34] H. Habazaki, M. Yamasaki, B. P. Zhang, a Kawashima, S. Kohno, T. Takai, K. Hashimoto, Appl. Catal. A Gen. 1998, 172, 131.

[35] R. Razzaq, H. Zhu, L. Jiang, U. Muhammad, C. Li, S. Zhang, Ind. Eng. Chem. Res. 2013, 52, 2247.

[36] J. G. McCarty, P. Y. Hou, D. Sheridan, H. Wise, in 'Coke Form. Met. Surfaces', Eds. L.F. Albright, R.T.K. Baker, ACS Symposium Series, American Chemical Society, Washington DC, 1983, pp. 253.

[37] P. R. Wentrcek, J. G. McCarty, B. J. Wood, H. Wise, Am. Chem. Soc. Div. Fuel Chem. Prep. 1976, 21,52

[38] J. R. Rostrup-Nielsen, Catal. Today 1997, 37, 225.

[39] J. G. McCarty, D. M. Sheridan, H. Wise, B. J. Wood, 'Hydrocarbon Reforming for Hydrogen Fuel Cells: A Study of Carbon Formation on Autothermal Reforming Catalysts', Final Report SRI International Corp., Menlo Park, CA, 1981.

[40] I. Czekaj, R. Struis, J. Wambach, S. M. A. Biollaz, Catal. Today 2011, 176, 429.

[41] M. D. Kaufman Rechulski, T. J. Schildhauer, S. M. A. Biollaz, C. Ludwig, Fuel 2014, 128, 330

[42] M. M. Yung, W. S. Jablonski, K. a. MagriniBair, Energy \& Fuels 2009, 23, 1874.

[43] R. P. W. J. Struis, T. J. Schildhauer, I. Czekaj, M. Janousch, S. M. A. Biollaz, C. Ludwig, Appl. Catal. A Gen. 2009, 362, 121.

[44] R. P. W. J. Struis, D. Bachelin, C. Ludwig, A. Wokaun, J. Phys. Chem. C 2009, 113, 2443.

[45] Y. Yu, G.-Q. Jin, Y.-Y. Wang, X.-Y. Guo, Fuel Process. Technol. 2011, 92, 2293.

[46] W. A. W. A. Bakar, R. Ali, S. Toemen, J. Nat. Gas Chem. 2011, 20, 585.

[47] M. Zangouei, A. Z. Moghaddam, M. Arasteh, Chem. Eng. Res. Bull. 2010, 14, 97.

[48] F. Loviat, I. Czekaj, J. Wambach, A. Wokaun, Surf. Sci. 2009, 603, 2210.

[49] A. Kampolis, Y. Liu, D. Ferri, F. J. Clemens, T. J. Schildhauer, O. Kröcher, in 23rd Eur. Biomass Conf. Exhib., 2015, pp. 1003-1007.

[50] A. Kambolis, D. Ferri, Y. Lu, S. N. Yannopoulos, S. Pokrant, D. Rentsch, O. Kröcher, ChemCatChem 2015, DOI 10.1002/ cetc. 201500567.

[51] M. A. Lucchini, A. Testino, C. Ludwig, A. Kambolis, M. El-Kazzi, A. Cervellino, P. Riani, F. Canepa, Appl. Catal. B Environ. 2014, 156, 404

[52] A. Fouskas, M. Kollia, A. Kambolis, C. Papadopoulou, H. Matralis, Appl. Catal. A Gen. 2014, 474,125 .

[53] M. Saeys, K. F. Tan, J. Chang, A. Borgna, Ind. Eng. Chem. Res. 2010, 49, 11098.

[54] J. Xu, L. Chen, K. Fei, A. Borgna, M. Saeys, J. Catal. 2009, 261, 158.

[55] J. Xu, M. Saeys, J. Phys. Chem. 2009, 113, 4099. 